\title{
Monoclonal Gammopathy of Undetermined Significance (MGUS) in a Man with Fragile X-associated Tremor/Ataxia Syndrome
}

\author{
Tanjung A. Sumekar, ${ }^{1,2}$ Aneel A. Ashrani, ${ }^{3}$ Tri I. Winarni, ${ }^{1,2}$ and Randi J. Hagerman ${ }^{1,4}$ \\ ${ }^{1}$ Medical Investigation of Neurodevelopmental Disorders (MIND) Institute, Davis Medical Center, University of California, \\ 2825 50th Street, Sacramento, CA 95817, USA \\ ${ }^{2}$ Division of Human Genetics, Center for Biomedical Research, Faculty of Medicine, Diponegoro University, \\ Jalan Dr. Sutomo No. 14, Semarang 50321, Indonesia \\ ${ }^{3}$ Division of Hematology, Department of Internal Medicine, College of Medicine, Mayo Clinic, 200 First Street SW, Rochester, \\ MN 55905, USA \\ ${ }^{4}$ Department of Pediatrics, Davis Medical Center, University of California, Sacramento, CA 95817, USA
}

Correspondence should be addressed to Randi J. Hagerman, randi.hagerman@ucdmc.ucdavis.edu

Received 16 September 2011; Accepted 19 October 2011

Academic Editors: A. Baumer and P. Saccucci

Copyright () 2011 Tanjung A. Sumekar et al. This is an open access article distributed under the Creative Commons Attribution License, which permits unrestricted use, distribution, and reproduction in any medium, provided the original work is properly cited.

We report the clinical presentation and laboratory findings of a 69-year-old man with fragile X-associated tremor ataxia syndrome (FXTAS), a progressive neurodegenerative disorder, who was noted to have monoclonal gammopathy of undetermined significance (MGUS), a plasma cell proliferative disorder and a precursor disease of multiple myeloma. Both MGUS and FXTAS are associated with microRNA (miRNA) dysregulation. We speculate that individuals with FXTAS may be predisposed to MGUS and further studies are warranted regarding this association.

\section{Introduction}

Fragile X-associated tremor/ataxia syndrome (FXTAS) is an adult progressive neurodegenerative disorder that affects predominantly male carriers of the fragile $\mathrm{X}$ mental retardation 1 (FMR1) gene premutation (CGG expansion of 55-200 repeats). The clinical features of FXTAS are progressive intention tremor, cerebellar ataxia, autonomic dysfunction, peripheral neuropathy, cognitive decline, middle cerebellar peduncle signs (MCPs), and white matter disease combined with brain atrophy on MRI [1-4].

The penetrance of FXTAS in male carriers older than age 50 is approximately 30 to $45.5 \%$ and 8 to $16.5 \%$ in females [2, $5,6]$. Overproduction of the FMR1 mRNA, up to 8 fold times normal, is the basic mechanism of FXTAS [7]. The elevated FMR1 mRNA causes a gain-of-function toxicity to cells leading to the formation of intranuclear inclusions in neurons and astrocytes throughout the central nervous system (CNS) and subsequent sequestration of critical proteins necessary for normal cell function $[8,9]$. Mitochondrial dysfunction also occurs in older premutation carriers both with and without FXTAS $[10,11]$. This cellular dysfunction leads to neuronal cell death and white matter disease in the CNS $[3,12,13]$ associated with the clinical features of FXTAS.

Monoclonal gammopathy of undetermined significance (MGUS) is a plasma cell proliferative disorder characterized by a plasma cell level of less than $10 \%$ in the bone marrow, a monoclonal paraprotein band less than $30 \mathrm{~g} / \mathrm{L}$, and no end organ damage (CRAB-hypercalcemia, renal insufficiency, anemia, and bone lesions) [14]. It is an age-related medical condition found predominantly in older persons [15]. The diagnosis of MGUS is usually an unexpected event during an evaluation, and because it is typically asymptomatic, it is underdiagnosed [16]. However, some abnormalities such as bone loss or osteoporosis, peripheral neuropathy, and thromboembolic events can be associated to this disorder [17]. Individuals with MGUS have a higher risk of developing multiple myeloma (MM) or related malignancy [18-20]. Race, ethinicity, advance age, male sex [15], family history [21], and exposure to certain pesticides [22] increase 
the risk of MGUS indicating that MGUS is a multifactorial condition.

The pathogenesis of MGUS is hypothesized to begin with an abnormal response to antigenic stimulation mediated by toll-like receptors (TLRs) and interleukin IL-6 receptors and IL-1 $\beta[23,24]$. This results in cytogenetic abnormalitieseither hyperdiploidy or immunoglobulin heavy chain $(\mathrm{IgH})$ translocations [25]. When it is followed by the second hit including RAS or p53 mutation, p18 deletion, myc dysregulation, MGUS progression to MM then occurs [26].

Dysregulation of microRNAs (miRNAs), the small noncoding RNAs involved in posttranscriptional gene regulation, plays a role in MGUS progression to MM [27]. MiRNAs have been demonstrated to play a role in regulation of apoptosis, proliferation, differentiation, cell survival, and oncogenesis [28]. Abnormal miRNA regulation may lead to oncogenesis, particularly MM [29-31]. The miRNA profiles discrepantly expressed in MGUS also show similar aberrant expression in MM suggesting the role of miRNAs in early myelomagenesis [27].

MiRNAs are encoded throughout the genome and are transcribed into pri-miRNA. The pri-miRNA is cleaved in the nucleus by the Drosha RNase III endonuclease. PremiRNAs are transported to the cytoplasm. In cytoplasm, Dicer, a ribonuclease III, cleaves the pre-miRNA into the mature miRNA which forms a complex with RNA-induced silencing complex (RISC). This complex directs the miRNA to the target mRNA leading either to degradation of target mRNA or translational repression [32]. In FXTAS patients, there is Drosha/DGCR8 sequestration by the elevated FMR1 mRNAs that leads to global miRNA dysregulation [33]. We speculate that this global miRNA dysregulation may predispose individuals to MGUS. Here we report the clinical presentation and laboratory findings of a man with FXTAS and MGUS.

\section{Clinical Report}

A 69-year-old Caucasian man with FXTAS had a premutation of 98 to 103 CGG repeats and an FMR1 mRNA level of $2.33 \pm 0.02$ times normal. His intention tremor began at age 55 and has been progressive. Currently, it interferes with his activities of daily living (ADL) including eating and handwriting. His gait imbalance began at age 58 and he started using a walker at age 66. His shortterm memory problems began at age 63 . His stamina has decreased significantly over the last few years and he has some decreased sensation in his lower legs in addition to pain with walking. He has autonomic dysfunction including bladder incontinence and erectile dysfunction beginning at age 66. His past medical history includes hypertension, type 2 diabetes, hyperlipidemia, hypothyroidism, sleep apnea, and migraine headaches (Table 1).

His family history includes a carrier daughter with fragile $\mathrm{X}$-associated primary ovarian insufficiency (FXPOI). His brother has had severe FXTAS with two surgeries for deep brain stimulation. His mother, a carrier, has also had tremor, cognitive decline, and non-Hodgkin's lymphoma and it is likely that she also has FXTAS.
TABLE 1: FXTAS clinical, neuroimaging, and molecular results of the patient.

\begin{tabular}{ll}
\hline Intention tremor & $\begin{array}{l}\text { began at age } 55 \\
\text { Postural tremor }(+) \\
\text { Kinetic tremor }(+) \\
\text { Right upper extremity }\end{array}$ \\
$\begin{array}{l}\text { Postural tremor }(+) \\
\text { Kinetic tremor }(+) \\
\text { beft upper extremity }\end{array}$ & began at age 58 \\
Handwriting problems 58 \\
Balance problem & Ataxic and broad based \\
Type of gait & Began at age 66 \\
Dependent on walker & Began at age 63 \\
Memory problems & $98-103$ (premutation range) \\
Fragile X DNA test (CGG repeat & \\
number) & $2.33 \pm 0.02$ times normal \\
FMR1 mRNA level & Definite \\
FXTAS diagnosis & 4 \\
FXTAS stage &
\end{tabular}

On physical examination, his blood pressure was $167 / 62 \mathrm{mmHg}$, the heart rate was $71 \mathrm{bpm}$, the head circumference was $59.5 \mathrm{~cm}$, his height was $172.7 \mathrm{~cm}$, and his weight was $87.5 \mathrm{~kg}$. The ears were slightly prominent. His neurological examination was abnormal with a severe intention tremor with finger to nose touching but absent at rest. There were no deep tendon reflexes but positive primitive reflexes including the snout reflex. His vibration sense was decreased in both feet. His gait was ataxic and broad based. He cannot tandem walk and he had a positive pull test. On MRI, he had significant brain atrophy and white matter disease including a positive MCP sign.

As a part of a workup for his mild normocytic anemia, serum protein electrophoresis with immunofixation revealed $1 \mathrm{~g} / \mathrm{dL}$ IgG kappa monoclonal paraproteinemia. His serum creatinine was mildly elevated at $1.3 \mathrm{mg} / \mathrm{dL}$ with estimated GFR of $55 \mathrm{~mL} / \mathrm{min}$. Calcium and highly sensitive $\mathrm{C}$-reactive protein were within the normal reference range. The quantitative immunoglobulins revealed normal IgG and IgA levels with decreased IgM $(17 \mathrm{mg} / \mathrm{dL}$; lower reference range $37 \mathrm{mg} / \mathrm{dL}$ ). The free kappa light chain is elevated at $7.81 \mathrm{mg} / \mathrm{dL}$ (upper reference range $1.92 \mathrm{mg} / \mathrm{dL}$ ) with normal lambda light chain $(1.88 \mathrm{mg} / \mathrm{dL})$. The kappa to lambda light chain ratio was elevated at 4.15 (upper reference range 1.65). The beta-2 microglobulin is elevated at $3.38 \mathrm{mcg} / \mathrm{mL}$ (upper reference range $1.8 \mathrm{mcg} / \mathrm{mL}$ ). The skeletal survey did not reveal any lytic or sclerotic lesions. The bone marrow biopsy revealed a normocellular marrow (30\% cellularity) with less than 5\% kappa light chain restricted plasma cells (Table 2).

\section{Discussion}

This is the first clinical report of MGUS in an individual with FXTAS. Although MGUS is an asymptomatic condition, it is associated with peripheral neuropathy, osteoporosis, and thromboembolic events. Symptoms shared by FXTAS and MGUS include peripheral neuropathy. His risk factors for 
TABLE 2: MGUS laboratory workup of the patient.

\begin{tabular}{|c|c|c|c|}
\hline & Levels & Reference range & \\
\hline Red cell count & 3.82 & $4.5-5.9 \mathrm{M} / \mathrm{MM} 3$ & Low \\
\hline Hemoglobin & 11.9 & 13.5-17.5 GM/DL & Low \\
\hline Hematocrit & 34.7 & $41-53 \%$ & Low \\
\hline Glucose & 358 & $70-110 \mathrm{mg} / \mathrm{dL}$ & High \\
\hline Hemagobin A1C & 8.5 & $3.9-5.9 \%$ & High \\
\hline Calcium & 9.5 & $8.6-10.5 \mathrm{mg} / \mathrm{dL}$ & Normal \\
\hline $\begin{array}{l}\text { Serum protein electrophoresis with } \\
\text { immunofixation }\end{array}$ & $1 \mathrm{~g} / \mathrm{dL}$ IgG kappa monoclonal paraproteinemia & & \\
\hline Serum creatinine & $1.3 \mathrm{mg} / \mathrm{dL}$ & $0.6-1.2 \mathrm{mg} / \mathrm{dL}$ & Mildly elevated \\
\hline GFR & 55 & $>60$ & Low \\
\hline $\operatorname{IgM}$ & $17 \mathrm{mg} / \mathrm{dL}$ & $37 \mathrm{mg} / \mathrm{dL}-50 \mathrm{mg} / \mathrm{dL}$ & Decreased \\
\hline Free kappa light chain & $7.81 \mathrm{mg} / \mathrm{dL}$ & $0.33-1.92 \mathrm{mg} / \mathrm{dL}$ & Elevated \\
\hline Lambda light chain & $1.88 \mathrm{mg} / \mathrm{dL}$ & $0.57-2.63 \mathrm{mg} / \mathrm{dL}$ & Normal \\
\hline Kappa to lambda light chain ratio & 4.15 & $0.26-1.65$ & Elevated \\
\hline Beta-2 microglobulin & $3.38 \mathrm{mcg} / \mathrm{mL}$ & $1.8 \mathrm{mcg} / \mathrm{mL}$ & Elevated \\
\hline Bone survey & & & No lytic or sclerotic lesions \\
\hline
\end{tabular}

developing an MGUS included advancing age, male sex, and having a mother with non-Hodgkin's lymphoma, a hematologic cancer. We also suggest that those with FXTAS have a greater risk for MGUS through the common finding of miRNA dysregulation in both disorders.

The DROSHA/DGCR8 sequestration mechanism in FXTAS leads to miRNA alteration, specifically downregulation of several miRNAs [33]. Thus, it may play a role in oncogenesis and tumor biology through posttrancriptional gene regulation impacting the mechanism of proliferation, differentiation, apoptosis, metastasis, and cell survival [28]. In MGUS, miRNAs play an important role in early changes associated with the development of the abnormal clonal plasma cell and have a potential role in altering the p53 pathway [29]. Downregulation or absence of miRNAs has been reported in many cancers [34], including other hemathologic malignancies such as acute myeloid leukemia [35], chronic lymphocytic leukemia [36], and diffuse large B-cell lymphoma [37].

It is unknown whether there is an increased risk of having cancer in those with a gene premutation, although there is one case report of a man with lung tumor and full mutation where the tumor's origin was in a cell with premutation instead of full mutation, indicating that the neoplasia development may have been facilitated by the premutation [38]. There is a relationship between elevated mRNA and cyclic adenosine monophosphate (cAMP) response-element binding protein (CREB). The elevated mRNA is due to increased trancription [7], while CREB is involved in FMR1 transcriptional activity [39] and may play a role in oncogenesis by various mechanisms including gene amplification, chromosome translocation, interaction with viral oncoprotein, and inactivation of tumor supressor genes [40].

The current report of MGUS and FXTAS combined with the commonality of miRNA mechanisms in these two conditions suggests that this association may be more common than previously realized and this deserves further study. One possibility is screening for the premutation when MGUS is identified. This would be very important if FXTAS symptoms are present or if there is a family history of fragile X-associated disorders including FXPOI or fragile X syndrome or autism.

\section{Conflict of Interests}

Dr. Hagerman has received funding from Novartis, Roche, Seaside Theurapetics, Forest and Curemark for therapeutic trials in fragile X syndrome and autism.

\section{Acknowledgments}

This work was supported by the National Institute of Health grants HD036071 and HD02274; Neurotherapeutic Research Institute (NTRI) grants DE019583 and DA024854; National Institute on Aging grants AG032119 and AG032115; National Center for Resources UL1 RR024146; and Health and Human Services Administration of Developmental Disabilities grant 90DD05969. The authors thank the family who participated to this study. The first author is addressee of Beasiswa Unggulan (The Excellent Scholarship) Program of The Bureau of Planning and International Cooperation, Ministry of National Education, Government of Indonesia.

\section{References}

[1] S. Jacquemont, R. J. Hagerman, M. Leehey et al., "Fragile $\mathrm{X}$ premutation tremor/ataxia syndrome: molecular, clinical, and neuroimaging correlates," American Journal of Human Genetics, vol. 72, no. 4, pp. 869-878, 2003.

[2] S. M. Coffey, K. Cook, N. Tartaglia et al., "Expanded clinical phenotype of women with the FMR1 premutation," American 
Journal of Medical Genetics, Part A, vol. 146, no. 8, pp. 10091016, 2008.

[3] J. S. Adams, P. E. Adams, D. Nguyen et al., "Volumetric brain changes in females with fragile X-associated tremor/ataxia syndrome (FXTAS)," Neurology, vol. 69, no. 9, pp. 851-859, 2007.

[4] E. Berry-Kravis, C. G. Goetz, M. A. Leehey et al., "Neuropathic features in fragile X premutation carriers," American Journal of Medical Genetics, Part A, vol. 143, no. 1, pp. 19-26, 2007.

[5] L. Rodriguez-Revenga, I. Madrigal, J. Pagonabarraga et al., "Penetrance of FMR1 premutation associated pathologies in fragile X syndrome families," European Journal of Human Genetics, vol. 17, no. 10, pp. 1359-1362, 2009.

[6] S. Jacquemont, R. J. Hagerman, M. A. Leehey et al., "Penetrance of the fragile $\mathrm{X}$-associated tremor/ataxia syndrome in a premutation carrier population," Journal of the American Medical Association, vol. 291, no. 4, pp. 460-469, 2004.

[7] F. Tassone, A. Beilina, C. Carosi et al., "Elevated FMR1 mRNA in premutation carriers is due to increased transcription," RNA, vol. 13, no. 4, pp. 555-562, 2007.

[8] D. Garcia-Arocena and P. J. Hagerman, "Advances in understanding the molecular basis of FXTAS," Human Molecular Genetics, vol. 19, no. 1, Article ID ddq166, pp. R83-R89, 2010.

[9] C. Sellier, F. Rau, Y. Liu et al., "Sam68 sequestration and partial loss of function are associated with splicing alterations in FXTAS patients," EMBO Journal, vol. 29, no. 7, pp. 12481261, 2010.

[10] C. Ross-Inta, A. Omanska-Klusek, S. Wong et al., "Evidence of mitochondrial dysfunction in fragile X-associated tremor/ataxia syndrome," Biochemical Journal, vol. 429, no. 3, pp. 545-552, 2010.

[11] E. Napoli, C. Ross-Inta, S. Wong et al., "Altered zinc transport disrupts mitochondrial protein processing/import in fragile X-associated tremor/ataxia syndrome," Human Molecular Genetics, vol. 20, no. 15, pp. 3079-3092, 2011.

[12] C. M. Greco, R. F. Berman, R. M. Martin et al., "Neuropathology of fragile X-associated tremor/ataxia syndrome (FXTAS)," Brain, vol. 129, part 1, pp. 243-255, 2006.

[13] R. Hashimoto, A. Javan, F. Tassone, R. J. Hagerman, and S. M. Rivera, "A voxel-based morphometry study of grey matter loss in fragile X-associated tremor/ataxia syndrome," Brain, vol. 134, no. 3, pp. 863-878, 2011.

[14] R. A. Kyle, J. A. Child, K. Anderson et al., "Criteria for the classification of monoclonal gammopathies, multiple myeloma and related disorders: a report of the International Myeloma Working Group," British Journal of Haematology, vol. 121, no. 5, pp. 749-757, 2003.

[15] R. A. Kyle, T. M. Therneau, S. V. Rajkumar et al., "Prevalence of monoclonal gammopathy of undetermined significance," The New England Journal of Medicine, vol. 354, no. 13, pp. 1362-1369, 2006.

[16] R. A. Kyle and S. Kumar, "The significance of monoclonal gammopathy of undetermined significance," Haematologica, vol. 94, no. 12, pp. 1641-1644, 2009.

[17] J. P. Bida, R. A. Kyle, T. M. Therneau et al., "Disease associations with monoclonal gammopathy of undetermined significance: a population-based study of 17,398 patients," Mayo Clinic Proceedings, vol. 84, no. 8, pp. 685-693, 2009.

[18] R. A. Kyle, "Monoclonal gammopathy of undetermined significance. Natural history in 241 cases," American Journal of Medicine, vol. 64, no. 5, pp. 814-826, 1978.

[19] R. A. Kyle, T. M. Therneau, S. V. Rajkumar, D. R. Larson, M. F. Plevak, and L. J. Melton, "Long-term follow-up of 241 patients with monoclonal gammopathy of undetermined significance: the original Mayo Clinic series 25 years later," Mayo Clinic Proceedings, vol. 79, no. 7, pp. 859-866, 2004.

[20] R. A. Kyle, “"Benign” monoclonal gammopathy-after 20 to 35 years of follow-up," Mayo Clinic Proceedings, vol. 68, no. 1, pp. 26-36, 1993.

[21] C. M. Vachon, R. A. Kyle, T. M. Therneau et al., "Increased risk of monoclonal gammopathy in first-degree relatives of patients with multiple myeloma or monoclonal gammopathy of undetermined significance," Blood, vol. 114, no. 4, pp. 785790, 2009.

[22] O. Landgren, R. A. Kyle, J. A. Hoppin et al., "Pesticide exposure and risk of monoclonal gammopathy of undetermined significance in the Agricultural Health Study," Blood, vol. 113, no. 25, pp. 6386-6391, 2009.

[23] G. Jego, R. Bataille, A. Geffroy-Luseau, G. Descamps, and C. Pellat-Deceunynck, "Pathogen-associated molecular patterns are growth and survival factors for human myeloma cells through toll-like receptors," Leukemia, vol. 20, no. 6, pp. 11301137, 2006.

[24] C. A. Dinarello, "Targeting the pathogenic role of interleukin $1 \beta$ in the progression of smoldering/indolent myeloma to active disease," Mayo Clinic Proceedings, vol. 84, no. 2, pp. 105107, 2009.

[25] P. L. Bergsagel and W. M. Kuehl, "Chromosome translocations in multiple myeloma," Oncogene, vol. 20, no. 40, pp. 56115622, 2001.

[26] P. L. Bergsagel and W. M. Kuehl, "Molecular pathogenesis and a consequent classification of multiple myeloma," Journal of Clinical Oncology, vol. 23, no. 26, pp. 6333-6338, 2005.

[27] K. R. Calvo, O. Landgren, A. M. Roccaro, and I. M. Ghobrial, "Role of microRNAs from monoclonal gammopathy of undetermined significance to multiple myeloma," Seminars in Hematology, vol. 48, no. 1, pp. 39-45, 2011.

[28] V. Ambros, "The functions of animal microRNAs," Nature, vol. 431, no. 7006, pp. 350-355, 2004.

[29] F. Pichiorri, S. S. Suh, M. Ladetto et al., "MicroRNAs regulate critical genes associated with multiple myeloma pathogenesis," Proceedings of the National Academy of Sciences of the United States of America, vol. 105, no. 35, pp. 12885-12890, 2008.

[30] Y. Zhoua, L. Chena, B. Barlogiea et al., "High-risk myeloma is associated with global elevation of miRNAs and overexpression of EIF2C2/AGO2," Proceedings of the National Academy of Sciences of the United States of America, vol. 107, no. 17, pp. 7904-7909, 2010.

[31] N. C. Gutiérrez, M. E. Sarasquete, I. Misiewicz-Krzeminska et al., "Deregulation of microRNA expression in the different genetic subtypes of multiple myeloma and correlation with gene expression profiling," Leukemia, vol. 24, no. 3, pp. 629637, 2010.

[32] D. P. Bartel, "MicroRNAs: genomics, biogenesis, mechanism, and function," Cell, vol. 116, no. 2, pp. 281-297, 2004.

[33] C. Sellier, P. Hagerman, and R. Willemsen, "DROSHA/ DGCR8 sequestration by expanded CGG repeats leads to global micro-RNA processing alteration in FXTAS patients [abstract]," in Proceedings of the 12th International Fragile $X$ Conference, Detroit, Mich, USA, 2010.

[34] J. Lu, G. Getz, E. A. Miska et al., "MicroRNA expression profiles classify human cancers," Nature, vol. 435, no. 7043, pp. 834-838, 2005.

[35] M. Jongen-Lavrencic, S. M. Sun, M. K. Dijkstra, P. J. M. Valk, and B. Löwenberg, "MicroRNA expression profiling in relation to the genetic heterogeneity of acute myeloid leukemia," Blood, vol. 111, no. 10, pp. 5078-5085, 2008. 
[36] R. Visone, L. Z. Rassenti, A. Veronese et al., "Karyotype-specific microRNA signature in chronic lymphocytic leukemia," Blood, vol. 114, no. 18, pp. 3872-3879, 2009.

[37] J. Zhang, D. D. Jima, C. Jacobs et al., "Patterns of microRNA expression characterize stages of human B-cell differentiation," Blood, vol. 113, no. 19, pp. 4586-4594, 2009.

[38] E. de Graaff, R. Willemsen, N. Zhong et al., "Instability of the CGG repeat and expression of the FMR1 protein in a male fragile X patient with a lung tumor," American Journal of Human Genetics, vol. 57, no. 3, pp. 609-618, 1995.

[39] K. T. Smith, R. D. Nicholls, and D. Reines, "The gene encoding the fragile X RNA-binding protein is controlled by nuclear respiratory factor 2 and the CREB family of transcription factors," Nucleic Acids Research, vol. 34, no. 4, pp. 1205-1215, 2006.

[40] Y. T. Siu and D. Y. Jin, "CREB — a real culprit in oncogenesis," FEBS Journal, vol. 274, no. 13, pp. 3224-3232, 2007. 


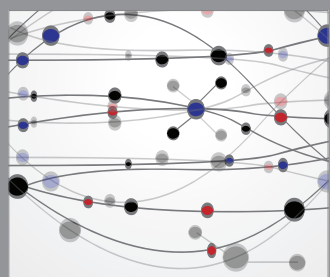

The Scientific World Journal
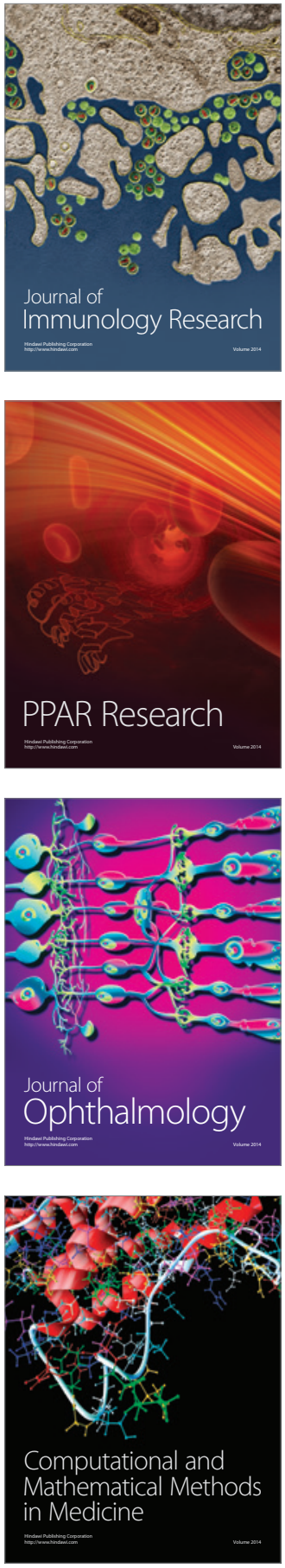

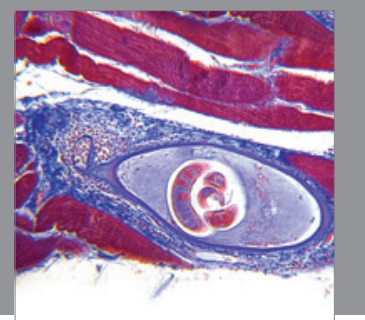

Gastroenterology

Research and Practice
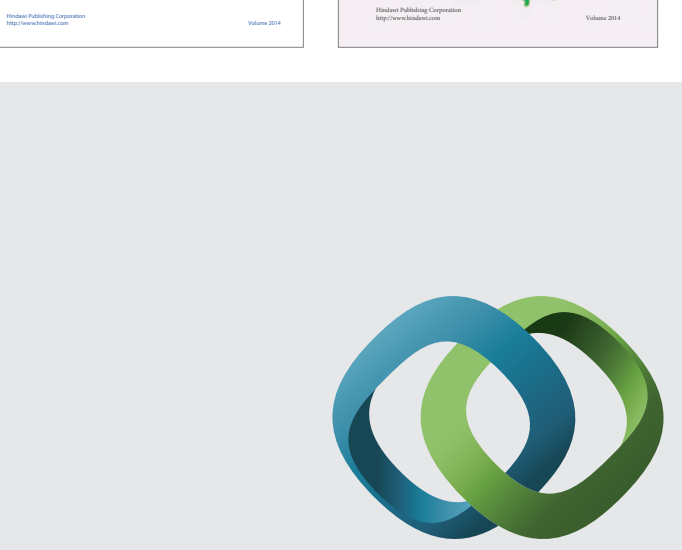

\section{Hindawi}

Submit your manuscripts at

http://www.hindawi.com
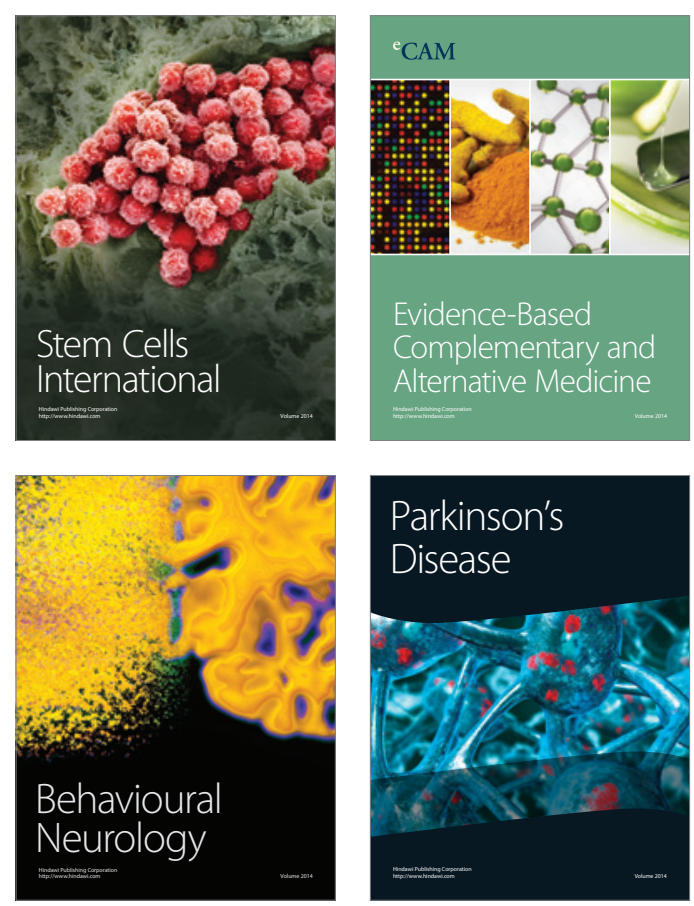

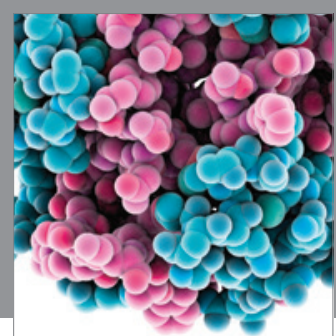

Journal of
Diabetes Research

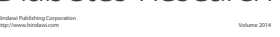

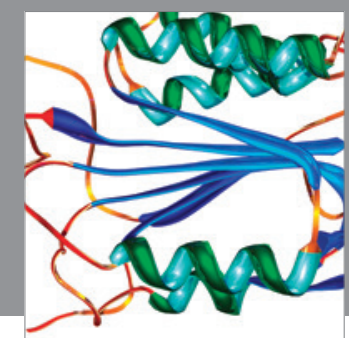

Disease Markers
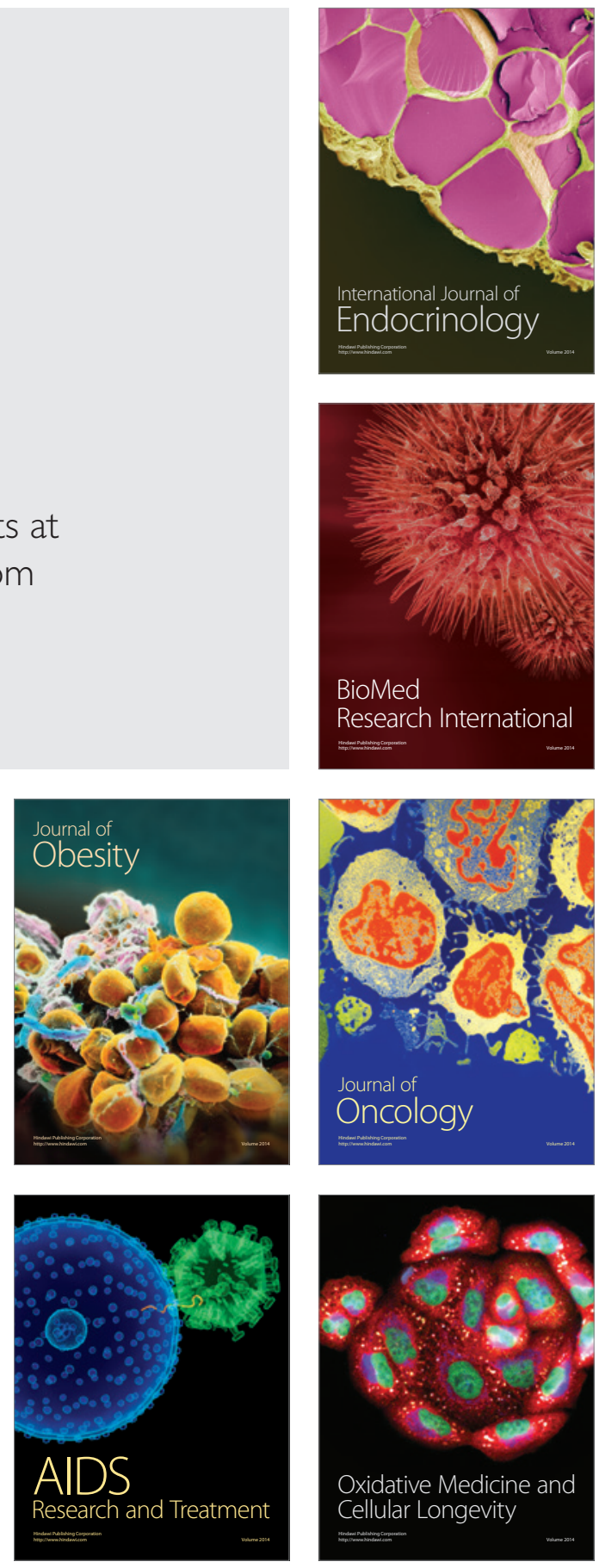